February 2005 - NREL/CP-520-37420

\title{
Combinatorial Optimization of Transparent Conducting Oxides (TCOs) for PV
}

J.D. Perkins, M.F.A.M. van Hest, C.W. Teplin, J.L. Alleman, M.S. Dabney, L.M. Gedvilas, B.M. Keyes, B. To, and D.S. Ginley National Renewable Energy Laboratory

M.P. Taylor and D.W. Readey Colorado School of Mines

A.E. Delahoy and S. Guo Energy Photovoltaics, Inc.

Prepared for the $31^{\text {st }}$ IEEE Photovoltaics Specialists Conference and Exhibition Lake Buena Vista, Florida January 3-7, 2005
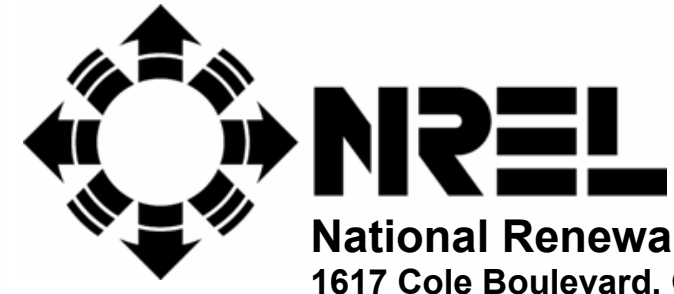

National Renewable Energy Laboratory 1617 Cole Boulevard, Golden, Colorado 80401-3393 303-275-3000 • www.nrel.gov

Operated for the U.S. Department of Energy Office of Energy Efficiency and Renewable Energy by Midwest Research Institute $\bullet$ Battelle 


\section{NOTICE}

The submitted manuscript has been offered by an employee of the Midwest Research Institute (MRI), a contractor of the US Government under Contract No. DE-AC36-99G010337. Accordingly, the US Government and MRI retain a nonexclusive royalty-free license to publish or reproduce the published form of this contribution, or allow others to do so, for US Government purposes.

This report was prepared as an account of work sponsored by an agency of the United States government. Neither the United States government nor any agency thereof, nor any of their employees, makes any warranty, express or implied, or assumes any legal liability or responsibility for the accuracy, completeness, or usefulness of any information, apparatus, product, or process disclosed, or represents that its use would not infringe privately owned rights. Reference herein to any specific commercial product, process, or service by trade name, trademark, manufacturer, or otherwise does not necessarily constitute or imply its endorsement, recommendation, or favoring by the United States government or any agency thereof. The views and opinions of authors expressed herein do not necessarily state or reflect those of the United States government or any agency thereof.

Available electronically at http://www.osti.gov/bridge

Available for a processing fee to U.S. Department of Energy and its contractors, in paper, from:

U.S. Department of Energy

Office of Scientific and Technical Information

P.O. Box 62

Oak Ridge, TN 37831-0062

phone: 865.576 .8401

fax: 865.576.5728

email: mailto:reports@adonis.osti.gov

Available for sale to the public, in paper, from:

U.S. Department of Commerce

National Technical Information Service

5285 Port Royal Road

Springfield, VA 22161

phone: 800.553 .6847

fax: 703.605.6900

email: orders@ntis.fedworld.gov

online ordering: http://www.ntis.gov/ordering.htm 


\title{
COMBINATORIAL OPTIMIZATION OF TRANSPARENT CONDUCTING OXIDES (TCOS) FOR PV
}

\author{
J.D. Perkins ${ }^{1}$, M.P. Taylor ${ }^{2}$, M.F.A.M. van Hest ${ }^{1}$, C.W. Teplin ${ }^{1}$, J.L. Alleman ${ }^{1}$, M.S. Dabney ${ }^{1}$, L.M. Gedvilas ${ }^{1}$, \\ B.M. Keyes ${ }^{1}$, B. To ${ }^{1}$, D.W. Readey ${ }^{2}$, A.E. Delahoy ${ }^{3}$, S. Guo ${ }^{3}$ and D.S. Ginley ${ }^{1}$ \\ ${ }^{1}$ National Renewable Energy Laboratory, Golden, CO 80401 \\ ${ }^{2}$ Colorado School of Mines, Golden, CO 80401 \\ ${ }^{3}$ Energy Photovoltaics, Inc., Princeton, NJ 08543
}

\begin{abstract}
Transparent conducting oxides (TCOs) can serve a variety of important functions in thin film photovoltaics such as transparent electrical contacts, antireflection coatings and chemical barriers. Two areas of particular interest are TCOs that can be deposited at low temperatures and TCOs with high carrier mobilities. We have employed combinatorial high-throughput approaches to investigate both these areas. Conductivities of $\sigma=2500 \Omega^{-1}-\mathrm{cm}^{-1}$ have been obtained for In-Zn-O (IZO) films deposited at $100{ }^{\circ} \mathrm{C}$ and $\sigma>5000 \Omega^{-1}-\mathrm{cm}^{-1}$ for In-Ti-O (ITiO) and In-Mo$\mathrm{O}$ (IMO) films deposited at $550{ }^{\circ} \mathrm{C}$. The highest mobility obtained was $83 \mathrm{~cm}^{2} / \mathrm{V}$-sec for ITiO deposited at $550{ }^{\circ} \mathrm{C}$.

\section{INTRODUCTION}

Transparent conducting oxides (TCOs) can serve a variety of important functions in thin film photovoltaics such as transparent electrical contacts, antireflection coatings and chemical barriers [1]. Two areas of particular interest are TCOs that can be deposited at low temperatures and TCOs with high carrier mobilities. In this study, we report on new high performance $\ln _{2} \mathrm{O}_{3}$-based materials substituted separately with $\mathrm{Zn}, \mathrm{Mo}$, and $\mathrm{Ti}$ [2-6]. We have employed combinatorial high-throughput approaches to investigate these materials $[2,3,7]$.
\end{abstract}

\section{EXPERIMENTAL APPROACH}

Compositionally graded samples ("libraries") are deposited by co-sputtering onto 2"x2" glass substrates [8]. Three to five libraries are generally required to cover the full composition range for a binary tie-line, such as from $\mathrm{In}_{2} \mathrm{O}_{3}$ to $\mathrm{ZnO}$. After deposition and, in some cases, additional controlled atmosphere annealing, the libraries are characterized by a variety of automated combinatorial mapping tools. At present, these include EPMA for metals stoichiometry, linear 4-point probe for sheet resistance [2], UV/VIS/NIR (200 - $2000 \mathrm{~nm}$ ) reflection and transmission, FTIR optical reflection and transmission $(1.8-25 \mu \mathrm{m})$ [9] and x-ray diffraction (XRD) using a large-area 2D detector [3]. For selected libraries, smaller samples are cut out for Hall effect measurements to determine the carrier concentration and mobility.

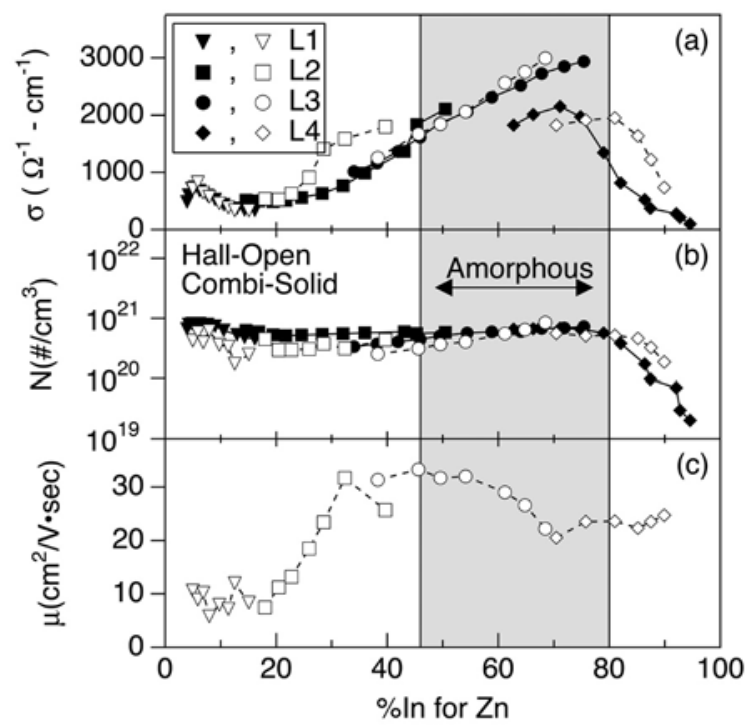

Fig. 1. Electrical conductivity (a), carrier concentration (b) and mobility (c) for In-Zn-O (IZO) deposited at $100^{\circ} \mathrm{C}$. Solid symbols are for data taken using automated combinatorial tools and open symbols are for data taken using a conventional Hall effect probe on individual cut out pieces.

\section{RESULTS AND DISCUSSION}

\section{In-Zn-O (IZO)}

For In-Zn-O (IZO) libraries deposited from ceramic oxide targets at $100{ }^{\circ} \mathrm{C}$ in Ar with no post-deposition annealing, a broad maximum in the conductivity with $\sigma \approx 2500$ $\Omega^{-1}-\mathrm{cm}^{-1}$ is found for $\mathrm{x} \sim 0.55$ to 0.75 in $\mathrm{Zn}_{1-\mathrm{x}} \ln _{\mathrm{x}} \mathrm{O}_{\mathrm{y}}$ (Fig. 1a). This roughly correlates with the composition range found to be amorphous by the XRD mapping. For higher In content, the carrier concentration decreases (Fig 1b) and for lower In content, the mobility decreases (Fig 1c). In Fig 1b, the combinatorially measured carrier concentration (solid symbols) is determined from the measured optical reflection and transmission spectra as described below. For samples with a composition in the amorphous region, the conductivity is unchanged by annealing for one 


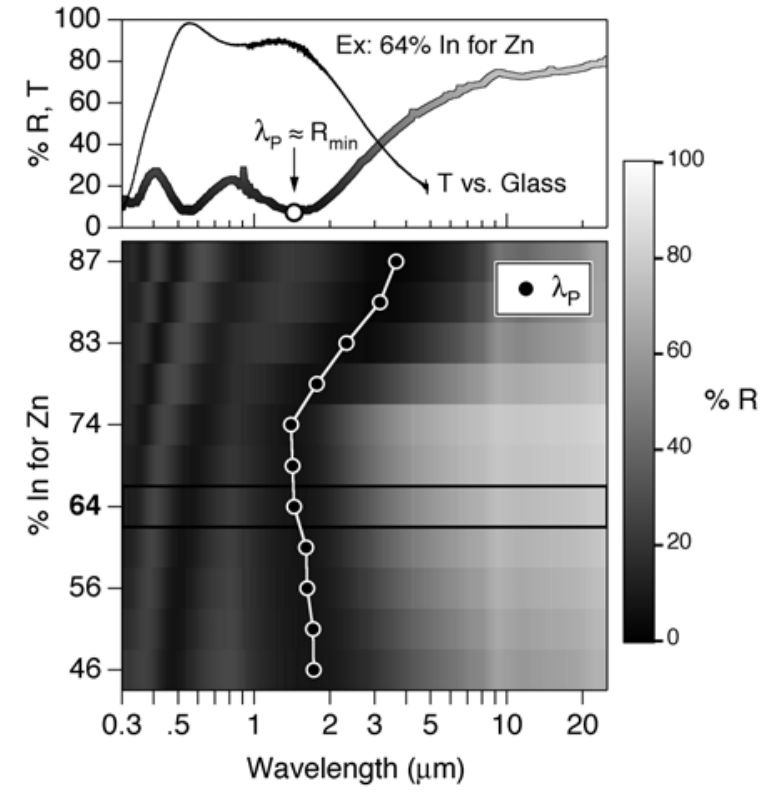

Fig. 2. Optical reflectance spectra for In-Zn-O (IZO) deposited at $100^{\circ} \mathrm{C}$. Top panel: Example spectra for one spot. Bottom panel: Reflectivity spectra for 11 compositions displayed using gray scale. The overlaid open white circles show the wavelength for $R_{\min }$ which approximately corresponds to $\lambda_{p}$.

hour in air at $200{ }^{\circ} \mathrm{C}$. Figure 2 shows the optical reflectivity from 0.3 to $25 \mu \mathrm{m}$ for an IZO library compositionally centered on the conductivity maximum. These samples are transparent in the visible region as evident from the spectra shown in the top panel and, in both panels, the overlaid open circles show the approximate plasma wave-

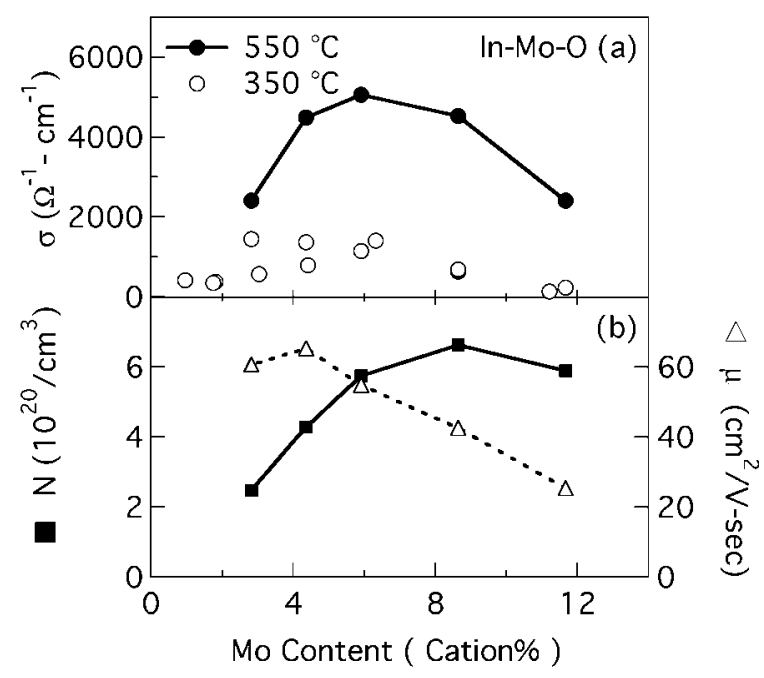

Fig. 3. Electrical conductivity (a), carrier concentration (b, left) and mobility (b, right) for In-Mo-O (IMO) for samples deposited at $350^{\circ} \mathrm{C}$ and $550^{\circ} \mathrm{C}$.

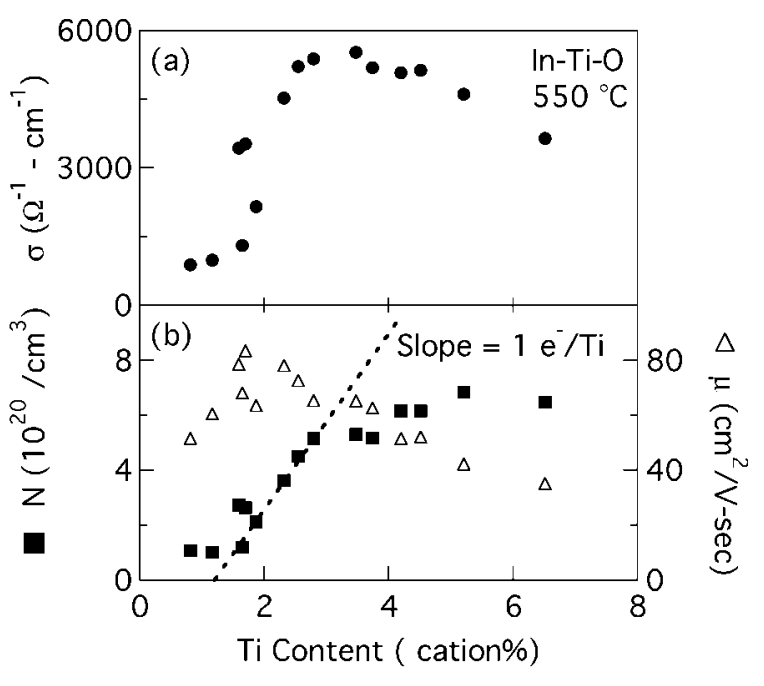

Fig. 4. Electrical conductivity (a), carrier concentration (b, left) and mobility (b, right) for In-Ti-O (ITiO) samples deposited at $550{ }^{\circ} \mathrm{C}$.

length $\left(\lambda_{p}\right)$. For most TCOs, the infrared optical properties are well described by a simple free-carrier (Drude) model [9] in which

$$
\lambda_{p} \propto \sqrt{\frac{m^{*}}{N}}
$$

where $\mathrm{m}^{*}$ is the electron effective mass and $\mathrm{N}$ is the electron carrier concentration. Hence, from the composition dependence of $\lambda_{p}$ (Fig. 2, bottom panel) one can determine the composition dependence of the carrier concentration across an entire library without having to cut the library into pieces for individual Hall measurements (Fig 1b.).

\section{In-Mo-O (IMO)}

For In-Mo-O (IMO) libraries deposited at $350{ }^{\circ} \mathrm{C}$, a maximum in the conductivity with $\sigma \approx 1000 \Omega^{-1}-\mathrm{cm}^{-1}$ is found for $\sim 6 \%$ Mo in place of In (Fig. 3a). Increasing the deposition temperature to $550{ }^{\circ} \mathrm{C}$ results in a five fold increase in the maximum conductivity to $\sigma \approx 5000 \Omega^{-1}-\mathrm{cm}^{-1}$. This is due to increases in both the carrier concentration and the mobility (Fig. 3b). In particular, for IMO samples grown at $550{ }^{\circ} \mathrm{C}$, the maximum mobility obtained is 65 $\mathrm{cm}^{2} \mathrm{~N}$-sec at $\sim 4 \% \mathrm{Mo}$ and the maximum carrier concentration is $6.6 \times 10^{20} / \mathrm{cm}^{3}$ at $\sim 8.5 \%$ Mo.

\section{In-Ti-O (ITiO)}

In addition, In-Ti-O (ITiO) has been investigated for use as a high mobility TCO (Fig. 4). For ITiO libraries deposited at $\mathrm{T}_{\mathrm{S}}=550{ }^{\circ} \mathrm{C}, \sigma \approx 5000 \Omega^{-1}-\mathrm{cm}^{-1}$ for $\sim 3$ to $4 \%$ $\mathrm{Ti}$ in place of In with a maximum mobility of $83 \mathrm{~cm}^{2} / \mathrm{V}-\mathrm{sec}$ at $\sim 2 \% \mathrm{Ti}$. For the sputtered ITiO samples, there is a 
linear increase in the carrier concentration of $3.4 \mathrm{x}$ $10^{20} / \mathrm{cm}^{3}$ per $\%$ Ti from $\sim 1.5$ to $3 \% \mathrm{Ti}$. This corresponds to 1.06 electrons / $\mathrm{Ti}$ indicating that for these growth conditions, $\mathrm{Ti}$ is a very effective dopant for $\ln _{2} \mathrm{O}_{3}$ contributing the expected 1 electron per dopant atom for Ti doping of $\mathrm{In}_{2} \mathrm{O}_{3}$. For comparison, in IMO films grown by pulsed laser deposition (PLD), Mo-doping yields $\sim 0.2-0.3$ electrons / Mo [5].

\section{SUMMARY}

We have employed combinatorial high-throughput approaches to investigate both these areas. Conductivities of $\sigma=2500 \Omega^{-1}-\mathrm{cm}^{-1}$ have been obtained for In-Zn-O (IZO) films deposited at $100{ }^{\circ} \mathrm{C}$ and $\sigma>5000 \Omega^{-1}-\mathrm{cm}^{-1}$ for In-Ti-O (ITiO) and In-Mo-O (IMO) films deposited at 550 ${ }^{\circ} \mathrm{C}$. The highest mobility obtained was $83 \mathrm{~cm}^{2} / \mathrm{V}$-sec for ITiO deposited at $550{ }^{\circ} \mathrm{C}$. Hence, IZO films should work well for applications requiring low-temperature deposition and processing such as TCO coatings onto flexible polymer substrates. Whereas, either IMO or ITiO films should work well for applications requiring a high carrier mobility such as devices requiring optical transparency in the infrared.

\section{REFERENCES}

[1] D. S. Ginley and C. Bright, "Transparent conducting oxides", MRS Bulletin 25, 2000, pp. 15-18.

[2] M. P. Taylor, D. W. Readey, C. W. Teplin, M. van Hest, J. L. Alleman, M. S. Dabney, L. M. Gedvilas, B. M. Keyes, B. To, P. A. Parilla, J. D. Perkins, and D. S. Ginley, "Combinatorial growth and analysis of the transparent conducting oxide ZnO/In (IZO)", Macromolecular Rapid Communications 25, 2004, pp. 344-347.

[3] M. P. Taylor, D. W. Readey, C. W. Teplin, M. F. A. M. van Hest, J. L. Alleman, M. S. Dabney, L. M. Gedvilas, B. M. Keyes, B. To, J. D. Perkins, and D. S. Ginley, "The electrical, optical and structural properties of $\ln _{x} Z_{1-x} \mathrm{O}_{y}$
$(0 \leq \mathrm{x} \leq 1)$ thin films by combinatorial techniques." Measurement Science and Technology 16, 2005, pp. 90-94.

[4] Y. Yoshida, D. M. Wood, T. A. Gessert, and T. J. Coutts, "High-mobility, sputtered films of indium oxide doped with molybdenum", Applied Physics Letters 84, 2004, pp. 2097-2099.

[5] C. Warmsingh, Y. Yoshida, D. W. Readey, C. W. Teplin, J. D. Perkins, P. A. Parilla, L. M. Gedvilas, B. M. Keyes, and D. S. Ginley, "High-mobility transparent conducting Mo-doped $\ln _{2} \mathrm{O}_{3}$ thin films by pulsed laser deposition", Journal of Applied Physics 95, 2004, pp. 3831-3833.

[6] A. E. Delahoy, L. Chen, B. Sang, S. Y. Guo, J. Cambridge, F. Ziobro, R. Govindarajan, S. Kleindienst, and M. Akhtar, "CIGS Devices, Modules, and Processing Using a Hybrid Evaporation/Sputtering Process", Proc. of the 19th European PVSEC, Paris, June 7-11, 2004.

[7] J. D. Perkins, J. A. del Cueto, J. L. Alleman, C. Warmsingh, B. M. Keyes, L. M. Gedvilas, P. A. Parilla, B. To, D. W. Readey, and D. S. Ginley, "Combinatorial studies of $\mathrm{Zn}-\mathrm{Al}-\mathrm{O}$ and $\mathrm{Zn}-\mathrm{Sn}-\mathrm{O}$ transparent conducting oxide thin films", Thin Solid Films 411, 2002, pp. 152.

[8] C. W. Teplin, M. van Hest, M. Dabney, C. L. Perkins, L. M. Gedvillas, B. To, P. A. Parilla, B. M. Keyes, J. D. Perkins, D. S. Ginley, Y. P. Lin, and Y. W. Lu, "Combinatorial study of reactively sputtered Cr-Ti-N", Applied Surface Science 223, 2004, pp. 253-258.

[9] J. D. Perkins, C. W. Teplin, M. van Hest, J. L. Alleman, X. Li, M. S. Dabney, B. M. Keyes, L. M. Gedvilas, D. S. Ginley, Y. Lin, and Y. Lu, "Optical analysis of thin film combinatorial libraries", Applied Surface Science 223, 2004, pp. 124-132. 


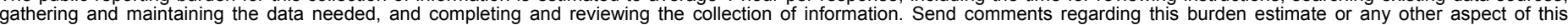

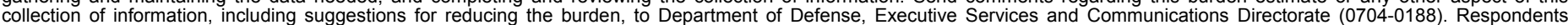

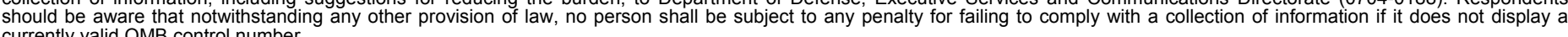

PLEASE DO NOT RETURN YOUR FORM TO THE ABOVE ORGANIZATION.

\section{REPORT DATE (DD-MM-YYYY) \\ February 2005 \\ 2. REPORT TYPE \\ Conference Paper}

4. TITLE AND SUBTITLE

Combinatorial Optimization of Transparent Conducting Oxides

(TCOs) for PV
3. DATES COVERED (From - To)

3-7 January 2005

5a. CONTRACT NUMBER

DE-AC36-99-G010337

5b. GRANT NUMBER

5c. PROGRAM ELEMENT NUMBER

5d. PROJECT NUMBER

NREL/CP-520-37420

5e. TASK NUMBER

PVA54201

5f. WORK UNIT NUMBER

\section{PERFORMING ORGANIZATION NAME(S) AND ADDRESS(ES)}

National Renewable Energy Laboratory, 1617 Cole Blvd., Golden, CO

80401-3393

Colorado School of Mines, Golden, CO 80401

Energy Photovoltaics, Inc., Princeton, NJ 08543

9. SPONSORING/MONITORING AGENCY NAME(S) AND ADDRESS(ES)

8. PERFORMING ORGANIZATION REPORT NUMBER

NREL/CP-520-37420
10. SPONSOR/MONITOR'S ACRONYM(S) NREL

11. SPONSORING/MONITORING AGENCY REPORT NUMBER

12. DISTRIBUTION AVAILABILITY STATEMENT

National Technical Information Service

U.S. Department of Commerce

5285 Port Royal Road

Springfield, VA 22161

\section{SUPPLEMENTARY NOTES}

\section{ABSTRACT (Maximum 200 Words)}

Transparent conducting oxides (TCOs) can serve a variety of important functions in thin-film photovoltaics such as transparent electrical contacts, antireflection coatings, and chemical barriers. Two areas of particular interest are TCOs that can be deposited at low temperatures and TCOs with high carrier mobilities. We have employed combinatorial highthroughput approaches to investigate both these areas. Conductivities of $\sigma=2500 \Omega^{-1}-\mathrm{cm}^{-1}$ have been obtained for In$\mathrm{Zn}-\mathrm{O}$ (IZO) films deposited at $100^{\circ} \mathrm{C}$ and $\sigma>5000 \Omega^{-1}-\mathrm{cm}^{-1}$ for In-Ti-O (ITiO) and In-Mo-O (IMO) films deposited at $550^{\circ} \mathrm{C}$. The highest mobility obtained was $83 \mathrm{~cm}^{2} / \mathrm{V}$-s for ITiO deposited at $550^{\circ} \mathrm{C}$.

\section{SUBJECT TERMS}

PV; transparent conducting oxides (TCOs); thin film; transparent electrical contacts; antireflection coatings; chemical barriers; polymer substrate;

16. SECURITY CLASSIFICATION OF:

\begin{tabular}{|l|c|l}
\hline $\begin{array}{c}\text { a. } \text { REPORT } \\
\text { Unclassified }\end{array}$ & $\begin{array}{c}\text { b. ABSTRACT } \\
\text { Unclassified }\end{array}$ & $\begin{array}{c}\text { c. THIS PAGE } \\
\text { Unclassified }\end{array}$ \\
\hline
\end{tabular}

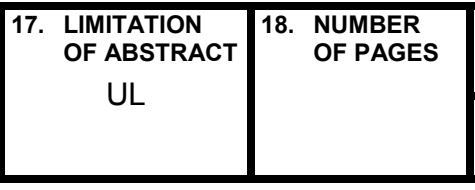

19a. NAME OF RESPONSIBLE PERSON

19b. TELEPHONE NUMBER (Include area code) 